\title{
Mass vegetative propagation of rare and endangered tree species of Indonesia by shoot cuttings by KOFFCO method and effect of container type on nursery storage of rooted cuttings
}

\author{
HENTI HENDALASTUTI RACHMAT ${ }^{1, \vartheta}$ ATOK SUBIAKTO ${ }^{1}$, ARIDA SUSILOWATI ${ }^{2,3, v \vee}$ \\ ${ }^{1}$ Forest Research and Development Center. Jl. Raya Gunung Batu No 5, Bogor 16118, West Java, Indonesia. \\ Tel.: +62-251-8633234, 7520067; Fax.:+62-251-8638111, `email: hendalastuti@yahoo.co.uk \\ ${ }^{2}$ Faculty of Forestry, Universitas Sumatera Utara. Jl. Tri Dharma Ujung No. 1, Kampus USU, Medan 20155, North Sumatra, Indonesia. \\ Tel./fax: +62-61-820-1920. " arida_iswanto@yahoo.co.id \\ ${ }^{3}$ Mangrove and Bio-resources Group. Center of Excellence for Natural Resources Based Technology, Universitas Sumatera Utara. Medan 20155, \\ North Sumatra, Indonesia
}

Manuscript received: 11 October 2018. Revision accepted: 20 November 2018.

\begin{abstract}
Rachmat HH, Subiakto A, Susilowati A. 2018. Mass vegetative propagation of rare and endangered tree species of Indonesia by shoot cuttings by KOFFCO method and effect of container type on nursery storage of rooted cuttings. Biodiversitas 19: $2353-2358$. The Forestry Research and Development Agency (FORDA) and The Advance Research of Komatsu Ltd have developed a mass propagation technique using shoot cuttings, namely KOFFCO system (Komatsu-FORDA Fog Cooling System). KOFFCO system controls environmental factors (temperature, humidity, and light intensity) to produce high percentage of rooted cuttings. The seed production of dipterocarp species is unreliable and unpredictable. Thus, vegetative propagation is an alternative means for producing planting materials of dipterocarp species. An attempt was made to produce rooted cuttings of rare and endangered dipterocarp and nondipterocarp species of the Indonesian native trees, for further use in both reforestation and plantation programs. In fact, this study attempts to answer two specific research questions: (i) What is the potential of KOFFCO system as a vegetative mass propagation technique for Indonesian dipterocarps and non-dipterocarps? (ii) What is the effect of container types on long-term post-nursery storage of dipterocarp planting stock? To answer the first question stated above, vegetative propagation through shoot cuttings of 24 species belonging to 7 genera of dipterocarps and 13 species belonging to 12 genera of non-dipterocarps was attempted ( $>30.000$ cuttings, in total), using KOFFCO system. The results showed that KOFFCO is an efficient innovative technology for the successful mass propagation from cuttings. 100\% root formation obtained for Nauclea orientalis, Anotephalus macrophyllus and Ficus sp. To find the answer for the second question, storage experiments and growth observations of the planting stock of selected dipterocarp species was performed, using three different types of containers. Rooted cuttings of six species of dipterocarps with same germination date were tested in each type of the container. The result showed that medium sized square and medium sized round containers produced an average height increment of $19.92 \mathrm{~cm}$ and $21.58 \mathrm{~cm}$, respectively, in a year, while small sized square containers produced only $13.94 \mathrm{~cm}$ height increment. Both square and round shaped containers are appropriate for short term storage of planting stock, while small containers are more appropriate for storing planting stocks or seedlings for a longer period.
\end{abstract}

Keywords: KOFFCO, cutting, mass propagation, dipterocarps

\section{INTRODUCTION}

Domination of Dipterocarps in tropical forests of South East Asia is undebatable. Dipterocarps are not only ecologically important but also economically significant (Bradshaw et al. 2009). 13 of the total 16 genera within the family, and about $92 \%$ of the 510 species belonging to this family grows naturally in the forests of Asia(Bawa 1998). Bradshaw et al. (2009) determined that the rate of tropical forest loss in Southeast Asia is greater than all other tropical regions. Adjers et al. (1995) stated that in the last two decades itself, at least seventy million hectares of forest was seriously depleted for which over exploitation and shifting cultivation were the main causes.

Establishing new forests in Indonesia and Malaysia has been mainly carried out by planting exotic trees such as Acacia and Eucalyptus. Contrary to most native tree species, silvicultural techniques for both Acacia and
Eucalyptus are widely available and advanced. Other considerations for establishing such exotic trees is that they show faster growth and higher resistance to environmental stress. While establishing plantations of exotic trees can guarantee timber supply in relatively short period of time, enrichment planting of commercially logged forests and establishment of commercial plantations using native or indigenous species offers greater benefits. In principal, restoring forest productivity for timber production is not the only criterion nowadays. Instead, recovering biodiversity and enhancing other environmental services are also receiving due considerations.

Depending on site and silvicultural techiques adapted, a 15 to 17 years old dipterocarps plantation could give the average diameter of 13.7 to $24.9 \mathrm{~cm}$ at breast height and the total volume ranged from $79.420 \mathrm{~m}^{3} / \mathrm{ha}-215.412 \mathrm{~m}^{3} / \mathrm{ha}$ (Subiakto et al. 2016). Considering the advanced technology in wood processing, producing timber of lower 
dimension may currently be acceptable. Thus the economics of dipterocarp plantations should be revisited.

Previous studies have shown that planting dipterocarps for both reforestation and plantation purpose has certain obstacles. Flowering and fruiting of dipterocarps is highly irregular with intervals of 2-10 years and the seed is categorized as recalcitrant with viability of less than a month after collection (Appanah 1993). Therefore, continuous supply of planting stocks is one of the major constraints. Difficulty in producing planting stock due to irregular fruiting and recalcitrant seed is the main reason for using vegetative propagation.

Difficulties in producing planting stocks due to irregularity of fruiting season and other seed characteristics such as recalcitrant are among the reasons for developing mass vegetative propagation. The Forestry Research and Development Agency (FORDA) and The Advance Research of Komatsu Ltd have developed a mass propagation technique from cuttings, namely KOFFCO system (Komatsu-FORDA Fog Cooling System). A unique feature of this innovative KOFFCO system, when compared to other more conventional techniques, is the presence of fog cooling system. The cooling mechanism contains sensor that will detect temperature higher than $30^{\circ} \mathrm{C}$, and this condition will trigger thermostat to activate high pressure pump and nozzles will spread fogging automatically. As fog gets evaporated, the heat inside the greenhouse is absorbed and this maintains temperature under $30^{\circ} \mathrm{C}$. Besides this, KOFFCO system also involves control of light intensity (5,000-20,000 lux) and humidity (above 95\%), by using shading net and propagation box (Subiakto and Sakai 2007). KOFFCO system has been adopted in many nurseries of commercial timber concessions or forestry services both in Kalimantan and Sumatera. This technique has also been adopted by students in conducting their research in many Universities. Further developments have broadened the scope of KOFFCO system to involve various aspects like exploration of wildings to raising and storing the planting stocks after post-nursery acclimatization, from just greenhouse and nursery management.

To support the growth of propagules obtained from cuttings, KOFFCO system requires greenhouse and nursery facilities. Root formation stage is the first phase in vegetative propagation which is conducted and supported inside the greenhouse facilities. During this stage, greenhouse requires facilities including propagation boxes, poly tubes, poly bags and fogging systems. The second stage is growth phase of rooted cuttings which is known as hardening. This phase is conducted and supported in the nursery and requires shading nets, watering system, poly tubes, poly bags, nursery benches, workshop for preparing cutting materials and transplanting phase. After these two stages are completed successfully, planting stocks can be directly planted in the field or kept for certain duration for others purposes. The use of different poly tubes/container types will determine the growth of the planting stocks, based on its specific storage purposes.
The purpose of the present study was to examine the potential of KOFFCO technology in the production of propagules of the Indonesian native tree species, for further use in both reforestation and plantation programs. In fact, it attempts to answer two specific research questions: (i) What is the potential of KOFFCO system as a vegetative mass propagation technique for Indonesian dipterocarps and non-dipterocarps? (ii) What is the effect of containers types on long-term post-nursery storage of dipterocarp planting stock?

\section{MATERIALS AND METHODS}

\section{Rooting of dipterocarps and non-dipterocarps}

The capability of KOFFCO system (Komatsu-FORDA Fog Cooling System) for mass propagation of dipterocarps and non-dipterocarps was studied. 37 species belonging to 19 genera of dipterocarps and non dipterocarps were propagated using more than 30,000 cutting materials, and the percentage of rooting of the cutting for each of the species. Study on propagation of dipterocarp and non dipterocarp species was carried out at KOFFCO greenhouse and nursery, Forest Research and Development Center (FRDC) and at the glass house and nursery of Faculty of Forestry, Sumatera Utara University (see Table 1 for details). On an average, about 6 months are required, after transplanting cuttings, to become ready-planting stocks (except for Dipterocarpus cinereus). Cutting media, root hormones, propagation box and greenhouse condition were set as described by Subiakto and Sakai (2007) with some minor modifications in the study conducted at Sumatera Utara University, such as absence of automatic cooling system, and manual observation of temperature and humidity. Rooting ability of the species (\%) was determined with a single treatment and number of cuttings used per species varied depending on the availability of source plants for cuttings.

\section{Effect of container type on nursery storage}

This study was carried out in a KOFCO (KomatsuFORDA Conservation) nursery at KOFCO greenhouse and nursery, FRDC, Bogor. Planting stocks of six species of dipterocarps was tested in three types of containers. The six species were: Vatica sumatrana Slooten ex. K. Heyne, Shorea pinanga Scheff, Shorea seminis Slooten, Shorea balangeran Burck, Shorea stenoptera Burck and Shorea chrysophylla Ridl. The containers tested were of three types, a) Type I, medium square containers (upper size 9 $\mathrm{cm} \times 9 \mathrm{~cm}$, height $10.6 \mathrm{~cm}$, base size $5.3 \times 5.3 \mathrm{~cm}), 15$ containers/tray; b) Type II, medium round containers (upper diameter $7.5 \mathrm{~cm}$, base diameter $5.5 \mathrm{~cm}$, height 10.8 $\mathrm{cm}), 15$ containers/tray; and c) Type III, small square containers (upper size $5.6 \mathrm{~cm}$ x $5.6 \mathrm{~cm}$, height $13 \mathrm{~cm}$, base size $3.3 \times 3.3 \mathrm{~cm}), 45$ containers/tray. Each species was replicated in three blocks/trays which consisted of five planting stocks having same germination date. 


\section{RESULTS AND DISCUSSION}

\section{Rooting ability of stem cuttings of dipterocarp and non- dipterocarp species}

The rooting ability of stem cuttings of 37 species belonging to 19 genera of dipterocarps and non dipterocarps was assessed. This data is useful to determine the potential of mass vegetative propagation of these species for reforestation projects and development of native tree plantations, and also germplasm conservation program. The rooting ability of each of the studied species, after 12 weeks of observation, is provided in Table 1 .

Propagation by stem cuttings of recalcitrant species requires high technical expertise to achieve an acceptable rooting percentage. Specialized facilities are required to produce rooted cuttings. In general, KOFFCO system provides high percentage of rooted cutting. Among 24 dipterocarp species tested, 16 species showed rooting ability of $>65 \%$, which means $67 \%$ of dipterocarps showed successful results and therefore they may be successfully propagated by this technique. 4 species e gave $50-65 \%$ rooted cuttings, and in case of remaining 4 species $(16.7 \%)$, some improvements or modifications are needed to get higher percentage of rooted cuttings since their rooting ability was $<50 \%$. Yeboah et al. (2011) stated that the presence of leaves on cuttings is also an important factor that determines the success of root formation in cuttings because leaves are important for root production. For dipterocarp species which have larger leaves, it is important to trim the leaves into half or one-third of their original size. By trimming the leaves, loss of water is reduced and root initiation is stimulated. This results in a higher rooting rate.

Table 1. Percentage of rooting of cuttings of dipterocarp and non-dipterocarp species by using KOFFCO system

\begin{tabular}{|c|c|c|c|c|c|}
\hline \multirow[b]{2}{*}{ Species } & \multirow[b]{2}{*}{ No.of cuttings } & \multirow{2}{*}{$\begin{array}{l}\text { No. of rooted } \\
\text { cutting }\end{array}$} & \multirow{2}{*}{$\begin{array}{c}\text { Rooting } \\
\text { percentage } \\
(\%)\end{array}$} & \multicolumn{2}{|c|}{ Conservation status } \\
\hline & & & & IUCN* & Indonesian ** \\
\hline Ficus sp. & 163 & 163 & 100 & NA & NA \\
\hline Nauclea orientalis & 45 & 45 & 100 & NA & NA \\
\hline Antocephalus macrophyllus & 45 & 45 & 100 & NA & NA \\
\hline Hopea odorata & 3375 & 3280 & 97.2 & Vul A2cd ver 3.1 & NA \\
\hline Anisoptera costata & 124 & 119 & 96.0 & En A2acd ver 3.1 & Priority $3^{3)}$ \\
\hline Syzigium oleina & 45 & 43 & 95.6 & NA & $\mathrm{NA}$ \\
\hline Styrax sumatrana ${ }^{\#)}$ & 60 & 55 & 91.67 & NA & NA \\
\hline Styrax benzoin ${ }^{\#)}$ & 60 & 55 & 91.67 & NA & NA \\
\hline Octomeles sumatrana & 90 & 82 & 91.1 & $\mathrm{LR} / \mathrm{LC}$ ver 2.3 & NA \\
\hline Shorea leprosula & 4500 & 4045 & 89.9 & NT ver 3.1 & NA \\
\hline Pinus merkusii & 80 & 70 & 87.5 & Vul B2ab (ii, iii,v) ver 3.1 & NA \\
\hline Shorea selanica & 12870 & 11214 & 87.1 & CR Alcd ver 2.3 & NA \\
\hline Vatica umbonata & 45 & 39 & 86.7 & LC ver 3.1 & NA \\
\hline Dryobalanops oblongifolia & 360 & 312 & 86.7 & LC ver 3.1 & NA \\
\hline Vatica sumatrana & 405 & 345 & 85.2 & NA & NA \\
\hline Shorea platyclados & 1890 & 1573 & 83.3 & En Alcd ver 2.3 & NA \\
\hline Shorea multiflora & 270 & 211 & 78.1 & LC ver 3.1 & NA \\
\hline Anisoptera marginata & 180 & 140 & 77.8 & En $A 1 c d+2 c d$ ver 2.3 & NA \\
\hline Eurycoma longifolia & 80 & 62 & 77.8 & NA & Managed ${ }^{4)}$ \\
\hline Shorea javanica & 720 & 555 & 77.1 & En B1ab (iii) ver 3.1 & Priority $3^{3)}$ \\
\hline Shorea balangeran & 900 & 686 & 76.2 & CR A1cd ver 2.3 & NA \\
\hline Shorea seminis & 111 & 82 & 73.9 & CR A1cd ver 2.3 & Protected ${ }^{1)}$ \\
\hline Dryobalanops sumatrensis & 108 & 79 & 73.1 & Vul A2cd ver 3.1 & Priority $2^{3)}$ \\
\hline Shorea guisso & 4095 & 2939 & 71.8 & NA & NA \\
\hline Cotylelobium melanoxylon & 125 & 89 & 71.2 & En $A 1 c d+2 c d$ ver 2.3 & NA \\
\hline Duabanga grandifolia & 226 & 137 & 60.7 & NA & NA \\
\hline Vatica javanica ssp. javanica & 30 & 18 & 60 & NA & Priority $1^{3)}$; Protected $^{2)}$ \\
\hline Eusideroxylon zwageri & 10 & 6 & 60 & Vul A1cd+2cd & Protected $^{2)}$ : Priority $3^{3)}$ \\
\hline Dryobalanops lanceolata & 121 & 67 & 55.4 & En A1cd ver 2.3 & NA \\
\hline Shorea curtisii & 130 & 69 & 53.1 & LC ver 3.1 & NA \\
\hline Shorea pinanga & 270 & 142 & 52.6 & NA & Protected ${ }^{1)}$; Priority $3^{3)}$ \\
\hline Shorea laevis & 56 & 24 & 42.9 & Vul A2cd ver 3.1 & NA \\
\hline Dipterocarpus retusus & 270 & 93 & 34.4 & En A2cd ver 3.1 & NA \\
\hline Taxus sumatrana & 80 & 24 & 30 & NA & Protected ${ }^{2)}$ \\
\hline Scaphium macropodum & 30 & 8 & 26.7 & LR/LC ver 2.3 & NA \\
\hline Dipterocarpus grandiflorus & 34 & 6 & 17.6 & En A2cd ver 3.1 & NA \\
\hline Dipterocarpus cinereus & 39 & 3 & 7.9 & CR D ver 3.1 & Protected ${ }^{2)}$ \\
\hline
\end{tabular}

Note: \# Experiment was carried out at glass house in Faculty of Forestry, North Sumatera University; * Based on The IUCN Red List of Threatened Species (www.iucnredlist.org/search): CR, critically endangered; En, endangered; Vul, vulnerable; LC, least concern; LR, Lower risk; NA, not assessed yet or not available; ** Indonesian rule and regulation for Plant protection ${ }^{1)} \mathrm{PP} 7 / 1999 ;{ }^{2)}$ Peraturan Menteri Lingkungan Hidup dan Kehutanan No 20 Tahun 2018; ${ }^{3)}$ Strategy and Conservation Action Priority (Priority 1-Priority 3); ${ }^{4)}$ Keputusan Menteri Pertanian No 511/Kpts/PD. 310/9/2006 
In general, stem cuttings taken from young seedlings of "difficult-to-root" tropical hardwood species root more easily than those taken from older (matured) plants. Juvenility of cutting source is also significant factor that affect rooting ability. Higher rooting percentage will be obtained from younger cutting source. KOFFCO system applied in this study resulted high rooting percentage $(97.25 \%)$ for Hopea odorata originated from 12 months old cutting source. Different technique developed by Forestry Department of Peninsular Malaysia (Forestry Department of Peninsular Malaysia 1998) produced more than $75 \%$ rooting ability for 6-12 month old Hopea odorata seedlings while for those of 18-21 month-old saplings only reached success rate less than $50 \%$.

The genus Vatica was rather easy to be propagated vegetatively using KOFFCO system since all two Vatica species propagated by KOFFCO system in this study showed very high rooting ability $(>85 \%)$. However, experiments conducted on the propagation of Vatica by cuttings employing non-KOFFCO technique showed that the rooting rate is under $50 \%$ (Momose 1978). Contrary to Vatica spp., propagation of Dipterocarpus spp. was rather difficult as all the three species studied showed very low percentage of rooting $(<50 \%)$. However, reportedly extinct Dipterocarpus cinereus was successfully propagated by shoot cutting in this study, though the percentage of rooting was as low as $8 \%$. This success, apparently due to modification of shade, is a big leap towards conservation of $D$. cinereus which is endemic and has a very small population size, considering the fact that earlier efforts to propagate this species were not successful (Rachmat and Subiakto 2015). Previous study has also recorded a very low propagation success rate of $15 \%$ for Dipterocarpus caudiferus (Ajik and Kimjus 2013). Slightly higher percentage of rooting obtained in this study by applying KOFFCO technique is, therefore, a good progress for this genus.

Some non-dipterocarp species such as Pinus merkusii, Styrax sumatrana, Styrax benzoin, etc. are also successfully propagated by KOFFCO system with high rooting capabilities. $87.5 \%$ rooting obtained for pine cuttings using $\mathrm{KOFFCO}$ in this study was higher compared to nonKOFFCO method in which rooting of only $75 \%$ has been reported (Corryanti and Rahmawati 2015). Propagation of important resin producing trees in North Sumatera (Styrax sumatrana and Styrax benzoin) using KOFFCO had also produced high rooting (Susilowati et al. 2017) compared to previous research conducted by Harahap (2012). But improvement in rooting is needed especially for Taxus sumatrana, considering the fact that cuttings were derived from older trees.

Previous study by Henselova et al. (2002) showed that successful rooting of stem cuttings was achieved by maintaining the temperature within $28^{\circ} \mathrm{C}$. NawrockaGrzeskowiak and Grzeskowiak (2003) working with Azalea shoot cuttings observed that a controlled temperature range of $20-25^{\circ} \mathrm{C}$ enhanced rooting performance. These findings are in accordance with the current application of KOFFCO technique in which temperature was always maintained under $30{ }^{\circ} \mathrm{C}$ and it seemed work well for most of the tested species. Relative humidity was always regulated at $95 \%$ or more as this is another important factor for rooting performance. Watering in KOFFCO technique was once in every two days and it is very important to avoid excess watering. Balestrini and Vartanian (1983) reported that water is important in vegetative propagation as it helps in maintaining relative humidity and reducing the temperature for cell division and other biochemical processes. However, excessive irrigation had a negative influence on rooting success (Erstad and Gislerod 1994; Rein et al. 1991).

\section{Effect of container type on nursery storage}

Favorable environmental conditions increases survival rate and allow trees to develop quickly until they can successfully compete for water, light and nutrients. Among all techniques applied in a nursery, a containerized seedling concept has gained its popularity to cope with rapid reforestation projects (Robert and Whitcom 1977). Containers are better alternatives to polybags in many aspects. Design of nursery containers effects posttransplant growth of several species (Gilman 2001; Struve 1993).

The choice of seedling size and container type, and their effects on post-planting performance is also of economic importance in production forestry. The growth of plants in containers is influenced by physical and chemical characteristics of the container environment, including container volume, shape and fertility (Keever and Cobb 1987). Stem cuttings of woody species can be rooted in numerous combinations of containers and substrates. However, container size, type and substrate can influence rooting percentage, root system quality and subsequent field growth. Generally, the type and volume of the containers are some of the most important characteristics, because they have both major and direct impacts on seedling quality and production costs. Meanwhile, the optimum container size varies according to many factors, including species, growing density, environmental conditions and length of the growing season (Tian et al. 2017). In this study, the the influence of container type on seedling growth of five species of Shorea and one species of Vatica was assessed for different storage durations of one month, six months and one year. Data on seedling height measured for different container types and sizes are as shown in Table 2 .

In general, medium sized square containers (15/tray) produced better growth of cuttings in the nursery when compared with rounded containers(15/tray) and small sized square containers(45/tray). According to Tian et al. (2017), increasing container size has a positive effect on seedling growth of many woody plant species. This finding is also supported by other research on plants like Elaeis guineensis (Akpo et al. 2014), Acacia koa (Dumroese et al. 2011), Eucalyptus citriodora (Vaknin et al. 2009) and Pinus pinea (Dommingguez-Lerena et al. 2006), all of which have indicated that parameters such as seedling height, rootcollar diameter, leaf production, and biomass increased with an increase in container size. Shoot growth is greatly impacted by varying container size and root restriction. 
Table 2. The effect of container type on seedling growth

\begin{tabular}{|c|c|c|c|c|}
\hline \multirow{2}{*}{$\begin{array}{l}\text { Container } \\
\text { type }\end{array}$} & \multirow{2}{*}{ Species } & \multicolumn{3}{|c|}{ Height (cm) } \\
\hline & & 1 month & 6 month & 12 month \\
\hline \multirow{7}{*}{$\begin{array}{l}\text { Medium } \\
\text { sized square } \\
\text { containers } \\
\text { (15/tray) }\end{array}$} & S. seminis & 18.53 & 38.47 & 66.6 \\
\hline & S. balangeran & 3.27 & 10.46 & 33 \\
\hline & S. stenoptera & 14.33 & 26.15 & 41.92 \\
\hline & S. crysophylla & 9.47 & 13.07 & 27.86 \\
\hline & S. pinanga & 25.8 & 60.07 & 71.13 \\
\hline & $V$. sumatrana & 12.8 & 28.93 & 56.13 \\
\hline & Average & 14.03 & 29.53 & 49.44 \\
\hline \multirow{7}{*}{$\begin{array}{l}\text { Round } \\
\text { containers } \\
\text { (15/tray) }\end{array}$} & S. seminis & 15.67 & 30.47 & 54 \\
\hline & S. balangeran & 3.53 & 10.14 & 40.86 \\
\hline & S. stenoptera & 21 & 37.21 & 55 \\
\hline & S. crysophylla & 6.2 & 11.29 & 28.57 \\
\hline & S. pinanga & 19.87 & 45.33 & 60.71 \\
\hline & $V$. sumatrana & 11.6 & 27.07 & 51.87 \\
\hline & Average & 12.98 & 26.92 & 48.50 \\
\hline \multirow{7}{*}{$\begin{array}{l}\text { Small sized } \\
\text { square } \\
\text { container } \\
\text { ( } 45 \\
\text { containers/ } \\
\text { tray) }\end{array}$} & S. seminis & 27.73 & 38.47 & 66.6 \\
\hline & S. balangeran & 3.87 & 10 & 26.47 \\
\hline & S. stenoptera & 14.4 & 30.92 & 34.2 \\
\hline & S. crysophylla & 6.6 & 11.71 & 20.5 \\
\hline & S. pinanga & 14.93 & 38.87 & 48.53 \\
\hline & V. sumatrana & 9.93 & 28.6 & 45.93 \\
\hline & Average & 12.91 & 26.43 & 40.37 \\
\hline
\end{tabular}

Larger container size can increase leaf area, shoot biomass and root biomass (Cantliffe 1993). Roots rely upon aerial portions of plants for photosynthates and various hormones, while plant aerial portions rely on roots for water, nutrients, support and hormones. The delicate balance between roots and shoots can be upset when the root system is restricted in a small rooting volume. The resulting imbalance can have short term as well as long term effects on plant growth. According to NeSmith and Dufal (1998), besides affecting root growth, container size has an effect also on shoot growth. when rooting volume decreased, less leaf area was produced. Shoot height and biomass reduction in small containers also have been reported in some species.

Container shapes (rounded or square or pyramidal) have varied effects on plant growth. According to Robert and Whitcom (1977), the behavior of roots in a round container is part of the root girdling problem. When a growing root confronts a barrier it cannot penetrate, it turns or buckles and follows the contour of the barrier. In a cylindrical container, no direction other than cyclic is provided and the root starts a spiral growth pattern around the container. Research by Davis and Whitcomb (1975) has shown that by using a square, bottomless container on a wire bench, the roots grow out until contacting the sides, then proceed to the 90 degree corner and grow downward. Based in this research, it is concluded that both medium sized square and round container produce higher growth than small sized square containers. However, considering the aspect of root growth, the use of square shaped containers is recommended because it is able to support root growth better than round shaped containers.

\section{ACKNOWLEDGEMENTS}

The authors wish to express their thanks to Project Collaboration between Forest Research and Development Center-KOMATSU, Indonesia for funding for this entire research and also to field technicians of Faculty of Forestry's nursery of Universitas Sumatera Utara for their hard work.

\section{REFERENCES}

Adjers G, Hadengganan S, Kuusipalo J, Nuryanto K, Vesa L. 1995. Enrichment planting of dipterocarps in logged-over secondary forests: effect of width, direction and maintenance method of planting line on selected Shorea species. For Ecol Manag 73: 259-270.

Ajik M, Kimjus K. 2013. An attempt to produce rooted cuttings from some selected dipterocarp species. Sepilok Bull 18: 57-68

Appanah S. 1993. Mass flowering of dipterocarp forests in the seasonal tropics. J Biosci 2: 457-474

Akpo E, Stomph TJ, Kossou DK, Omore AO, Struik PC. 2014. Effects of nursery management practices on morphological quality attributes of tree seedlings at planting: The case of oil palm (Elaeis guineensis

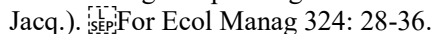

Bawa KS. 1998. Conservation of genetic Resources in the Dipterocarpaceae. Biogeography and evolutionary Systematics of Dipterocarpaceae. In: Apannah S, Turnbull JM (eds.). A Review of Dipterocarps: Taxonomy, Ecology and Sylviculture. CIFOR, Bogor .

Balestrini S, Vartanian N. 1983. Rhizogenic activity during water stressinduced senescence in Brassica napus var oleifera. Physiologie Vegetale 21: 269-277.

Bradshaw CJA, Sodhi NS, Brook BW. 2009 Tropical turmoil: a biodiversity tragedy in progress. Front Ecol Environ 7: 79-87.

Cantliffe DJ. 1993. Pre-and postharvest practices for improved vegetable transplant quality. Hort Technol 3: 415-417

Corryanti, Rahmawati R. 2015. Terobosan memperbanyak Pinus merkusii. Puslitbang Perum Perhutani, Jakarta. [Indonesian]

Davis RE, Whitcomb CE. 1975. Effects of propagation container size on development of high quality tree seedlings. Proc. Int. Plant Prop. Soc 25: $251-257$

Dominguez-Lerena S, Herrero Sierra N, Carrasco Manzano I, Ocaña Bueno L, Peñuelas Rubira JL, Mexal JG. 2006. Container characteristics influence Pinus pinea seedling development in the nursery and field. For Ecol Manag 221, 63-71.

Dumroese RK, Davis AS, Jacobs DF. 2011. Nursery response of Acacia koa seedlings to container size, irrigation method, and fertilization rate. J Plant Nutr 34: 877-887.

Erstad JLF, Gislerod HR. 1994. Water uptake and stem pieces as affected by different anaerobic conditions in the rooting medium. Scientia Horticulturae 58: 151-160.

Forestry Department of Peninsular Malaysia. 1998. Guidelines to Propagate Dipterocarp Species by Stem Cutings. Malaysia-ITTO Project. PD 185/91 REV 2(F): PHASE 1. Forestry Department of Peninsular Malaysia, Kuala Lumpur.

Gilman EF. 2001. Effect of nursery production method, irrigation, and inoculation with mycorrhizae-forming fungi on establishment of Quercus virginia. J Arboricult 27 (1): 30-38.

Harahap I. 2012. Pengaruh Konsentrasi dan Lama Perendaman Growtone terhadap Pertumbuhan Stek Pucuk Kemenyan (Styrax tonkinensis). Fakultas Pertanian, Universitas Simalungun, Simalungun. [Indonesian]

Henselova M, Lux A, Masarovicava E. 2002. Effect of growth regulators on rooting cuttings of Karwinskia species under in vivo conditions. Rostlinna Vyroba 48 10: 471-476.

IUCN. 2012. IUCN Red List Categories and Criteria. Version 3.1. 2nd ed. IUCN Species Survival Commission. Gland, Switzerland.

Keever GJ, Cobb JS. 1987. Effects of container volume and fertility rate on growth of two woody ornamentals. Hort Sci 22: 891-893.

Momose Y. 1978. Vegetative propagation of Malaysian trees. Malaysian Forester 41 (3): 219-223. 
Nawrocka-Grzeskowiak U, Grzeskowiak W. 2003. Rooting of Azalea shoot cuttings depending on the degree of lignification. Dendrobiology 49: 53-56.

NeSmith DS, Dufal JS. 1998. The effect of container size. Hort Technol 8 4. hort/transplant/trans_cs1.pdf https://swfrec.ifas.ufl.edu/docs/pdf/veg-

Rachmat HH, Subiakto A. 2015. Conserving the previously reported extinct tree species Dipterocarpus cinereus: An ex-situ approach for the species conservation strategy. Biodiversitas 16: 560-564

Rein RH, Wright RD, Seiler JR. 1991. Propagation medium moisture level influences adventitious rooting of woody stem cuttings. J Amer Soc Hort Sci 116: 632-636.

Robert DH, Whitcom CE. 1977. Propagation of Quercus seedling in bottomless container with osmocote. J Arboricult 3 (11): 218-212.

Subiakto A, Rachmat HH, Sakai C. 2016. Choosing native tree species for establishing man-made forest: A new perspective for sustainable forest management in changing world. Biodiversitas 17 2: 620-625

Subiakto, A, Sakai C. 2007. Manajemen persemaian KOFFCO yystem. Pusat Penelitian dan Pengembangan Hutan dan Konservasi Alam, Bogor. [Indonesian]
Susilowati A, Sri Hartini KH, Rachmat HH, Alvaroby M. 2017. Propagation of valuable North Sumatera benzoin trees (Styrax Sp) using macrocutting technique. IOP Conf. Series: Materials Science and Engineering $180: 012046$. DOI: 10.1088/1757899X/180/1/012046

Struve DK. 1993. Effect of copper-treated containers on transplant survival and regrowth of four tree species. J Environ Hortic 11: 196199

Tian N, Fang S, Yang W, Shang X, Fu X. 2017. Influence of container type and growth medium on seedling growth and root morphology of Cyclocarya paliurus during nursery culture. Forests 8: 1-16.

Vaknin Y, Dudai N, Murkhovsky L, Gelfandbein L, Fischer R, Degani A. Effects of pot size on leaf production and essential oil content and composition of Eucalyptus citriodora Hook. J Herbs Spices Med Plants 15: 164-176.

Yeboah J, Lowor ST., Amoah FM, Owusu-Ansah F. 2011. Propagating structures and some factors that affect the rooting performance of Shea (Vitellaria paradoxa Gaertn) stem cuttings. Agric Biol J N Am 22 (2): 258-269. 